\title{
Pseudosphingobacterium domesticum gen. nov., sp. nov., isolated from home-made compost
}

Correspondence

Célia M. Manaia cmmanaia@esb.ucp.pt

\author{
Ivone Vaz-Moreira, ${ }^{1}$ M. Fernanda Nobre, ${ }^{2}$ Olga C. Nunes ${ }^{3}$ \\ and Célia M. Manaia ${ }^{1}$ \\ ${ }^{1}$ Escola Superior de Biotecnologia, Universidade Católica Portuguesa, 4200-072 Porto, \\ Portugal \\ ${ }^{2}$ Departamento de Zoologia, Universidade de Coimbra, 3004-517 Coimbra, Portugal \\ ${ }^{3}$ LEPAE - Departamento de Engenharia Química, Faculdade de Engenharia, \\ Universidade do Porto, 4200-465 Porto, Portugal
}

\begin{abstract}
A bacterial strain, $\mathrm{DC}-186^{\top}$, isolated from home-made compost, was characterized for its phenotypic and phylogenetic properties. The isolate was a Gram-negative rod that was able to grow at $15-36^{\circ} \mathrm{C}$ and $\mathrm{pH} 5.5-8.0$. Strain $\mathrm{DC}-186^{\top}$ was positive in tests for catalase, oxidase and $\beta$-galactosidase activities and aesculin hydrolysis. The predominant fatty acids were the summed feature $\mathrm{C}_{16: 1}$ /iso- $\mathrm{C}_{15: 0} 2-\mathrm{OH}(42 \%)$ and iso- $\mathrm{C}_{15: 0}(26 \%)$, the major respiratory quinone was menaquinone-7 and the genomic DNA G $+C$ content was 42 mol\%. 16S rRNA gene sequence analysis and phenetic characterization indicated that this organism belongs to the phylum Bacteroidetes and revealed its affiliation to the family Sphingobacteriaceae. Of recognized taxa, strain DC-186 ${ }^{\top}$ was most closely related to Sphingobacterium daejeonense (90\% sequence similarity) based on 16S rRNA gene sequence analysis. The low 16S rRNA gene sequence similarity with other recognized taxa and the identification of distinctive phenetic features for this isolate support the definition of a new genus within the family Sphingobacteriaceae. The name Pseudosphingobacterium domesticum gen. nov., sp. nov. is proposed, with strain DC-186 ${ }^{\top}$ $\left(=\right.$ CCUG $54353^{\top}=$ LMG $\left.23837^{\top}\right)$ as the type strain.
\end{abstract}

In a study of culturable heterotrophic bacteria in composts, a Gram-negative bacterium, strain DC- $186^{\mathrm{T}}$, affiliated to the family Sphingobacteriaceae, was isolated from home-made compost. This strain presented a unique genotype (revealed through random amplified polymorphic DNA and repetitive extragenic palindromic-PCR analysis) among the bacterial isolates recovered from the same compost. Those organisms were predominantly members of the genus Bacillus and pseudomonads. Strain DC- $186^{\mathrm{T}}$ was further characterized using a polyphasic approach.

The bacterial isolate was recovered on Plate Count Agar (PCA) at $30^{\circ} \mathrm{C}$ and purified by subculturing on the same medium. Long-term preservation was made in modified Luria-Bertani medium (MLB) (Tiago et al., 2004), supplemented with $15 \%(\mathrm{v} / \mathrm{v})$ glycerol, at $-80{ }^{\circ} \mathrm{C}$. PCA was used for culture maintenance and biochemical and physiological tests were performed in MLB incubated at $30^{\circ} \mathrm{C}$. Colony and cell morphology, Gram-staining, cytochrome $c$ oxidase and catalase tests, accumulation of poly- $\beta$-hydroxybutyrate

Abbreviation: FAMEs, fatty acid methyl esters.

The GenBank/EMBL/DDBJ accession number for the 16S rRNA gene sequence of $\mathrm{DC}-186^{\top}$ is $\mathrm{AM} 407725$. granules and motility were analysed based on the methodologies of Murray et al. (1994) and Smibert \& Krieg (1994). Growth and colony morphology on selective/differential agar media were tested on Membrane Faecal Coliform (mFC), Eosin Methyl Blue (EMB) and MacConkey media. The ability to grow at $\mathrm{pH} 5.5,8.0$ and 9.0 was examined in culture medium supplemented with commercial buffers (12 mM MES, $12 \mathrm{mM}$ TAPS and $12 \mathrm{mM}$ CAPS, respectively; all from Sigma). Growth was also tested in MLB supplemented with $1,3,5$ and $7 \%(\mathrm{w} / \mathrm{v}) \mathrm{NaCl}$, at $15,22,30$, 36 and $40{ }^{\circ} \mathrm{C}$ and under anaerobiosis $\left(\mathrm{N}_{2}\right.$-saturated atmosphere) in the presence of $0.1 \%(\mathrm{w} / \mathrm{v}) \mathrm{KNO}_{3}$. The production of extracellular amylases, gelatinases and Tweenases (Tween 80) was tested as described by Tiago et al. (2004). Antibiotic susceptibility phenotypes were assayed as described previously (Ferreira da Silva et al., 2006), following the interpretation criteria proposed by the Comite de l'Antibiogramme de la Société Française de Microbiologie (1998). Growth in mineral medium was tested in medium B (Barreiros et al., 2003) supplemented with $4 \mathrm{mM}\left(\mathrm{NH}_{4}\right)_{2} \mathrm{SO}_{4}$ and $20 \mathrm{mM}$ mannose in $100 \mathrm{ml}$ screw-capped Erlenmeyer flasks containing $10 \mathrm{ml}$ medium, incubated at 120 r.p.m. Other biochemical and nutritional tests were performed using the API 20E, API 20NE and API 50CH galleries (bioMérieux) 
according to the manufacturer's instructions. API $50 \mathrm{CH}$ carbon source utilization was examined using both the medium recommended to test acid production $(50 \mathrm{CHB} / \mathrm{E}$; bioMérieux) and mineral medium $\mathrm{B}$ with $\left(\mathrm{NH}_{4}\right)_{2} \mathrm{SO}_{4}$.

For determination of the genomic DNA G + C content, DNA was extracted based on the method of Cashion et al. (1977) and G + C ratios were estimated using the HPLC method as described by Mesbah et al. (1989). For analysis of respiratory quinones, freeze-dried cells were extracted according to Tindall (1989) and extracts were analysed by HPLC-UV (Knauer) at $260 \mathrm{~nm}$ with a Lichrosphere $5 \mu \mathrm{m}$ RP-18 column (Merck). A methanol/hexane (75:25, v/v) mixture was used as mobile phase at a flow rate of $1 \mathrm{ml}$ $\min ^{-1}$. Retention times were compared with known standards. Fatty acid methyl esters (FAMEs) were analysed in $24 \mathrm{~h}$ cultures on tryptic casein soy agar. Harvesting of the cells and preparation of FAMEs were performed as described by Kuykendall et al. (1988). The separation, identification and quantification of the individual FAMEs were made using the Microbial Identification System, Sherlock version 4.6 (MIS-MIDI). FAMEs were extracted and analysed twice.

The nucleic acid sequence of the 16S rRNA gene was determined after PCR amplification of total DNA extracts as described previously (Rainey et al., 1996). The 16S rRNA gene sequence was compared with others available in GenBank/EMBL/DDBJ using BLASTN from NCBI and aligned with reference sequences. Phylogenetic analysis was conducted using Molecular Evolutionary Genetics Analysis (MEGA) software, version 3.1 (Kumar et al., 2004). Sequence relatedness was estimated based on the model of Jukes \& Cantor (1969) and the phylogenetic tree was created using the neighbour-joining method. Other methods, namely maximum-parsimony, minimum-evolution and unweighted pair group analysis with arithmetic mean, were used to assess tree stability. A total of $1193 \mathrm{nt}$ positions in each 16S rRNA gene was included in the analysis. Nonhomologous and ambiguous nucleotide positions were excluded from the calculations.

After $24 \mathrm{~h}$ incubation at $30^{\circ} \mathrm{C}$ on PCA, strain DC- $186^{\mathrm{T}}$ formed yellowish, mucilaginous colonies with a diameter of 2-3 mm. White colonies were produced on EMB after $24 \mathrm{~h}$ incubation, whereas colonies were blue/dark on m-FC agar after 3 days. Growth did not occur on MacConkey agar after 7 days incubation. Cells were non-motile, Gram-negative, short rods. Growth occurred at $15-36{ }^{\circ} \mathrm{C}$, with optimal growth at $30^{\circ} \mathrm{C}$. At $5 \% \mathrm{NaCl}$, growth was slow and weak. No growth was observed at $40{ }^{\circ} \mathrm{C}$, pH 9 or in $7 \% \mathrm{NaCl}$. Strain DC- $186^{\mathrm{T}}$ did not require specific organic growth factors, namely vitamins or amino acids, as concluded from the fact that this organism presented strong growth in mineral medium with mannose as sole carbon source. Several sugars, but not organic acids, were assimilated by strain DC- $186^{\mathrm{T}}$. Nitrate was reduced to nitrite, but not used as an alternative electron acceptor under anaerobic conditions. Strain DC-186 ${ }^{\mathrm{T}}$ was able to grow in the presence of cephalothin, ceftazidime, gentamicin, streptomycin, tetracycline and colistin sulphate, but not in the presence of ciprofloxacin, sulfamethoxazole, sulfamethoxazole/trimethoprim or meropenem. The major fatty acids of strain $\mathrm{DC}-186^{\mathrm{T}}$ were summed feature 3 $\left(\mathrm{C}_{16: 1} \omega 7 c / \mathrm{C}_{16: 1} \omega 6 c /\right.$ iso- $\left.\mathrm{C}_{15: 0} 2-\mathrm{OH}\right)$ and iso- $\mathrm{C}_{15: 0}$, which accounted for about $70 \%$ of the total (Table 1). The major respiratory quinone was menaquinone- 7 and the $\mathrm{G}+\mathrm{C}$ content of the genomic DNA was $42 \mathrm{~mol} \%$.

The genera Pedobacter and Sphingobacterium are members of the family Sphingobacteriaceae (Euzéby, 1997). Common phenotypic characteristics of members of the genera Pedobacter and Sphingobacterium are production of catalase and oxidase, hydrolysis of aesculin, the presence of $\beta$-galactosidase and utilization of a large number of carbohydrates and of few organic acids and amino acids (Steyn et al., 1998; Kim et al., 2006). Chemotaxonomic markers of these genera are the presence of MK-7 and sphingolipids, a genomic DNA G $+\mathrm{C}$ content of around $40 \mathrm{~mol} \%$ and a characteristic FAME pattern (Steyn et al., 1998; Kim et al., 2006). They also have iso- $\mathrm{C}_{15: 0}$, iso- $\mathrm{C}_{15: 0} 2-\mathrm{OH}$, iso- $\mathrm{C}_{15: 0}$ $3-\mathrm{OH}, \mathrm{C}_{16: 0}, \mathrm{C}_{16: 1} \omega 07 c, \mathrm{C}_{16: 0} 3-\mathrm{OH}$ and iso- $\mathrm{C}_{17: 0} 3-\mathrm{OH}$ as the predominant fatty acids. All these properties were observed in strain DC-186 $6^{\mathrm{T}}$, thus confirming the affiliation

Table 1. Fatty acid contents of strain DC- $186^{\top}$ and type strains of related species

Taxa: 1, strain DC-186 ${ }^{\mathrm{T}}$; 2, Sphingobacterium daejeonense LMG $23402^{\mathrm{T}}$ (data from Kim et al., 2006); 3, Sphingobacterium spiritivorum NBRC $14948^{\mathrm{T}}$ (Steyn et al., 1998); 4 Pedobacter heparinus LMG $10339^{\mathrm{T}}$ (Steyn et al., 1998). Values are percentages of total fatty acid methyl esters. Components that made up less than $1 \%$ of the total are summed as 'Other' and included $\mathrm{C}_{14: 0}$ 2-OH, anteiso- $\mathrm{C}_{15: 0}, \mathrm{C}_{15: 1} \omega 6 c, \mathrm{C}_{14: 0}$ 3-OH/iso- $\mathrm{C}_{16: 1}, \mathrm{C}_{15: 0} 3-\mathrm{OH}$, iso$\mathrm{C}_{16: 0} 3-\mathrm{OH}, \mathrm{C}_{16: 1} \omega 5 c, \mathrm{C}_{16: 1}$ 2-OH, iso- $\mathrm{C}_{17: 0}$ and $\mathrm{C}_{20: 0}$. - , Not detected; SF, identified as part of a summed feature.

\begin{tabular}{|lcccc|}
\hline Fatty acid & $\mathbf{1}$ & $\mathbf{2}$ & $\mathbf{3}$ & $\mathbf{4}$ \\
\hline $\mathrm{C}_{14: 0}$ & 1.4 & - & 1.0 & 1.1 \\
$\mathrm{C}_{15: 0}$ & - & - & - & 1.1 \\
iso- $_{15: 0}$ & 25.9 & 45.6 & 30.1 & 28.2 \\
iso- $\mathrm{C}_{15: 0} 2-\mathrm{OH}$ & $\mathrm{SF}^{*}$ & $\mathrm{SF}^{\dagger}$ & 21.5 & 10.4 \\
iso- $\mathrm{C}_{15: 0} 3-\mathrm{OH}$ & 2.0 & 1.5 & 2.2 & 2.5 \\
$\mathrm{C}_{16: 0}$ & 7.6 & 3.4 & 3.5 & 3.0 \\
$\mathrm{C}_{16: 0} 2-\mathrm{OH}$ & 2.8 & - & - & - \\
$\mathrm{C}_{16: 0} 3-\mathrm{OH}$ & 3.3 & - & 2.7 & 1.5 \\
$\mathrm{C}_{16: 1} \omega 7 c$ & $\mathrm{SF}$ & $\mathrm{SF} \dagger$ & 21.1 & 20.2 \\
iso- $\mathrm{C}_{17: 0} 3-\mathrm{OH}$ & 11.1 & 16.6 & 12.5 & 15.2 \\
iso- $\mathrm{C}_{17: 1} \omega 9 c$ & 1.3 & 2.9 & 1.7 & 6.3 \\
Summed feature & $42.2^{*}$ & $23.8 \dagger$ & - & - \\
Other & 2.4 & 6.2 & 3.7 & 10.5 \\
\hline
\end{tabular}

${ }^{*}$ Summed feature corresponds to $\mathrm{C}_{16: 1} \omega 7 c / \mathrm{C}_{16: 1} \omega 6 c /$ iso- $\mathrm{C}_{15: 0} 2-\mathrm{OH}$ (Sherlock MIS-MIDI, version 4.6).

$\dagger$ Summed feature corresponds to $\mathrm{C}_{16: 1} \omega 7 \mathrm{c} /$ iso- $\mathrm{C}_{15: 0}$ 2-OH (Kim et al., 2006). 
Table 2. Distinctive characteristics of strain $D C-186^{\top}$ and related species

Taxa: 1, strain DC- $186^{\mathrm{T}}$; 2, Sphingobacterium daejeonense LMG $23402^{\mathrm{T}}$ (data from Kim et al., 2006); 3, Sphingobacterium spiritivorum NBRC $14948^{\mathrm{T}}$ (Kim et al., 2006; Steyn et al., 1998); 4, Pedobacter heparinus LMG $10339^{\mathrm{T}}$ (Steyn et al., 1998). +, Positive; -, negative; NA, no available data; $\mathrm{v}$, variable.

\begin{tabular}{|c|c|c|c|c|}
\hline Characteristic & 1 & 2 & 3 & 4 \\
\hline \multicolumn{5}{|l|}{ Growth at: } \\
\hline $42^{\circ} \mathrm{C}$ & - & + & - & NA \\
\hline pH 9.0 & - & + & NA & NA \\
\hline Nitrate reduction & + & NA & - & - \\
\hline \multicolumn{5}{|l|}{ Hydrolysis of: } \\
\hline Starch & + & - & + & NA \\
\hline Aesculin & + & - & + & + \\
\hline Gelatin & + & - & - & - \\
\hline Acetoin production & - & + & NA & + \\
\hline \multicolumn{5}{|l|}{ Acid production from: } \\
\hline Sucrose & + & - & + & $\mathrm{V}$ \\
\hline L-Arabinose & + & - & - & $\mathrm{V}$ \\
\hline \multicolumn{5}{|l|}{ Assimilation of: } \\
\hline L-Arabinose & + & - & - & + \\
\hline D-Adonitol & - & + & - & + \\
\hline L-Rhamnose & - & - & + & + \\
\hline D-Mannitol & - & - & + & + \\
\hline D-Raffinose & + & + & + & - \\
\hline DNA G $+\mathrm{C}$ content $(\mathrm{mol} \%)$ & 42 & 39 & 40 & $42-43$ \\
\hline
\end{tabular}

of this isolate to the family Sphingobacteriaceae (Steyn et al., 1998).

The distinctive phenotypic properties of strain DC- $186^{\mathrm{T}}$ (Table 2) and the low 16S rRNA gene sequence similarity observed between this organism and other genera of the family Sphingobacteriaceae support the proposal of a new genus. The closest phylogenetic neighbour of strain DC$186^{\mathrm{T}}$ was 'Pocheonia soli' (GenBank/EMBL/DDBJ accession no. AB267715), with $98 \%$ 16S rRNA gene sequence similarity (D. An and S. Lee, unpublished results). Among recognized taxa, Sphingobacterium daejeonense (Kim et al., 2006) was the closest relative to strain DC- $186^{\mathrm{T}}$, with $90 \%$ $16 \mathrm{~S}$ rRNA gene sequence similarity. As in the present study, S. daejeonense TR6-0 $4^{\mathrm{T}}$ was isolated from a compost sample. Besides the low 16S rRNA gene sequence similarity between strain DC- $186^{\mathrm{T}}$ and its closest phylogenetic neighbours (Fig. 1), several phenotypic features enable this strain to be differentiated from its relatives (Table 2). These results support the description of a novel species, in a new genus, represented by isolate DC- $186^{\mathrm{T}}$, for which the name Pseudosphingobacterium domesticum sp. nov. is proposed.

\section{Description of Pseudosphingobacterium gen. nov.}

Pseudosphingobacterium (Pseu.do'sphing.o.bac.ter.i.um. Gr. adj. pseudes false; N.L. neut. n. Sphingobacterium a bacterial generic name; N.L. neut. n. Pseudosphingobacterium false Sphingobacterium).

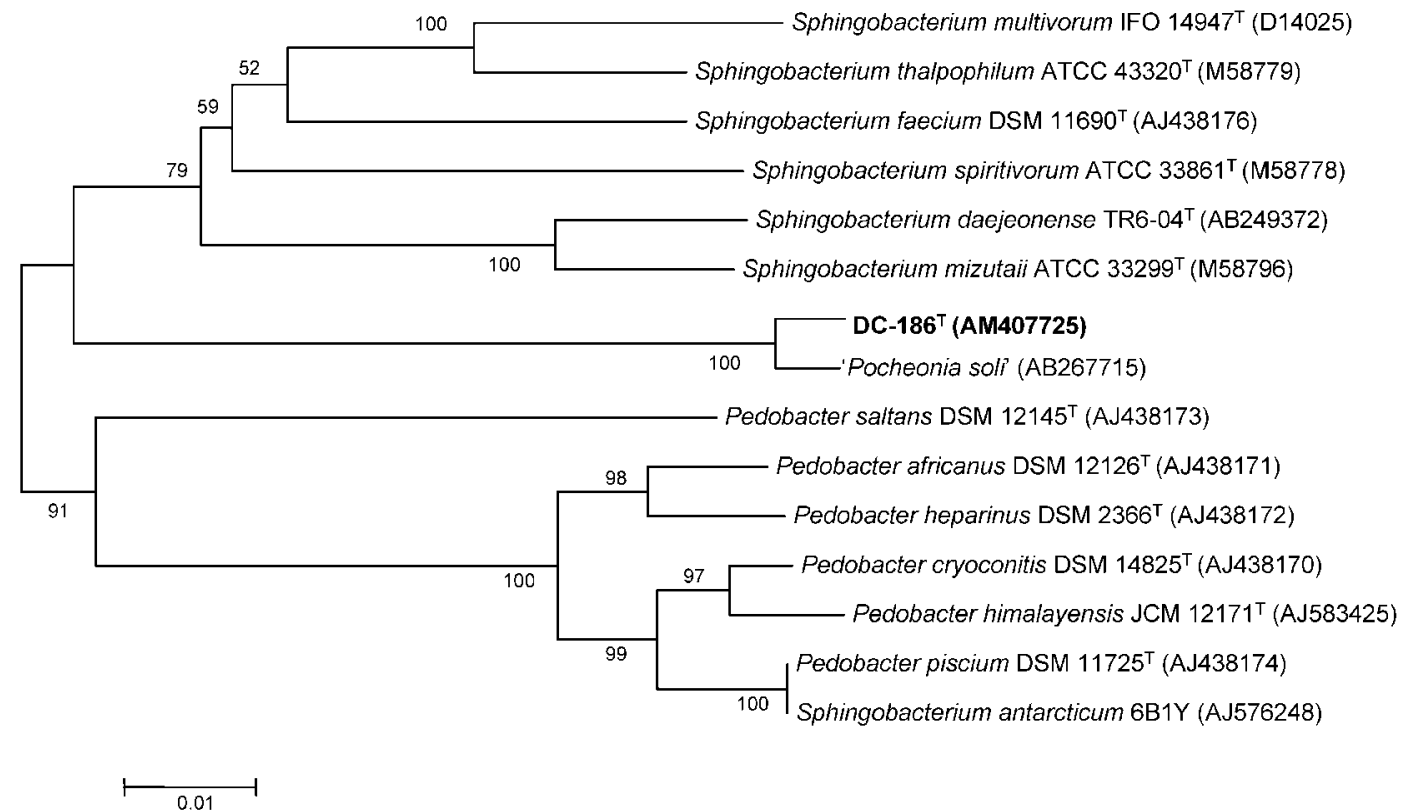

Fig. 1. Phylogenetic tree constructed using the neighbour-joining method based on $16 \mathrm{~S}$ rRNA gene sequences showing the nearest neighbours of strain $\mathrm{DC}-186^{\top}$. Bootstrap values were generated from 10000 resamplings. Bar, 1 substitution per $100 \mathrm{nt}$ positions. 
Cells are non-spore-forming, Gram-negative, non-motile rods. Poly- $\beta$-hydroxybutyrate inclusions are not observed. Positive for catalase, oxidase, aesculin hydrolysis and $\beta$ galactosidase. Negative for arginine dihydrolase, lysine and ornithine decarboxylases, urease, tryptophan deaminase, citrate utilization and $\mathrm{H}_{2} \mathrm{~S}$, indole and acetoin production. Mesophilic. No specific growth factors are required. Nitrate is reduced to nitrite, but does not support anaerobic growth. Sugars are used as single carbon sources. Chemo-organoheterotrophic and strictly aerobic. Major respiratory quinone is menaquinone-7. Species of the genus have a DNA $\mathrm{G}+\mathrm{C}$ content of around $40 \mathrm{~mol} \%$. The summed feature $\mathrm{C}_{16: 1} /$ iso- $\mathrm{C}_{15: 0} 2-\mathrm{OH}$, iso- $\mathrm{C}_{15: 0}$ and iso- $\mathrm{C}_{17: 0} 3-\mathrm{OH}$ are the predominant fatty acids. The type species is Pseudosphingobacterium domesticum.

\section{Description of Pseudosphingobacterium domesticum sp. nov.}

Pseudosphingobacterium domesticum (dom.es.ti.cum. L. neut. adj. domesticum of or belonging to the house).

Displays the following properties in addition to those given in the genus description. On nutritive non-selective medium, colonies are yellowish, smooth and mucilaginous. Cells are short rods $(1.2-1.5 \times 0.5-0.6 \mu \mathrm{m})$. Growth occurs on EMB and m-FC agar, but not on MacConkey agar. Growth occurs at $15-36^{\circ} \mathrm{C}$ and $\mathrm{pH} 5.5-8.0$, but not at $40^{\circ} \mathrm{C}$ or $\mathrm{pH}$ 9. Growth occurs in the presence of $3 \% \mathrm{NaCl}$, but not in $7 \% \mathrm{NaCl}$. Growth may occur in the presence of the following antibiotics: cephalothin, ceftazidime, gentamicin, streptomycin, tetracycline and colistin sulphate. No growth in the presence of ciprofloxacin, sulfamethoxazole or meropenem. Gelatin and starch are hydrolysed, but Tween 80 is not hydrolysed. No specific nutritional growth factors such as vitamins or amino acids are required. Assimilation and acid production is positive for $\mathrm{N}$-acetylglucosamine, amygdalin, L-arabinose, D-cellobiose, D-fructose, D-galactose, D-glucose, D-lactose, D-maltose, D-mannose, D-melibiose, methyl $\alpha$-D-glucopyranoside, D-raffinose, sucrose, D-trehalose and D-xylose. D-Arabinose, arbutin and methyl- $\alpha$-Dmannopyranoside support acid production, whereas salicin, starch and D-turanose are assimilated. Acid production or assimilation is negative for other API $50 \mathrm{CH}$ and API $20 \mathrm{NE}$ carbon sources. The major fatty acid is summed feature $\mathrm{C}_{16: 1}$ /iso- $\mathrm{C}_{15: 0}$ 2-OH. The $\mathrm{G}+\mathrm{C}$ content of genomic DNA of strain DC- $186^{\mathrm{T}}$ is $42 \mathrm{~mol} \%$.

The type strain, DC- $186^{\mathrm{T}} \quad\left(=\right.$ CCUG $54353^{\mathrm{T}}=\mathrm{LMG}$ $\left.23837^{\mathrm{T}}\right)$, was isolated from home-made compost.

\section{Acknowledgements}

Authors acknowledge Luísa Barreiros and Patrícia Reis for their helpful collaboration, Margarida Silva (Centro de Estudos Ambientais da Escola Superior de Biotecnologia) for supplying the home-made compost and Milton S. da Costa (Departamento de Bioquímica da Faculdade de Ciências e Tecnologia da Universidade de Coimbra) for supporting the fatty acid methyl ester analyses.

\section{References}

Barreiros, L., Nogales, B., Manaia, C. M., Ferreira, A. C. S., Pieper, D. H., Reis, M. A. \& Nunes, O. C. (2003). A novel pathway for mineralization of the thiocarbamate herbicide molinate by a defined bacterial mixed culture. Environ Microbiol 5, 944-953.

Cashion, P., Holder-Franklin, M. A., McCully, J. \& Franklin, M. (1977). A rapid method for the base ratio determination of bacterial DNA. Anal Biochem 81, 461-466.

Comité de l'Antibiogramme de la Société Française de Microbiologie (1998). Communiqué du Comité de l'Antibiogramme de la Société Française de Microbiologie. Bull Soc Fr Microbiol 13, 243-258.

Euzéby, J. P. (1997). List of Bacterial Names with Standing in Nomenclature: a folder available on the Internet. Int J Syst Bacteriol 47, 590-592. http://www.bacterio.net

Ferreira da Silva, M., Tiago, I., Verissimo, A., Boaventura, R. A., Nunes, O. C. \& Manaia, C. M. (2006). Antibiotic resistance of enterococci and related bacteria in an urban wastewater treatment plant. FEMS Microbiol Ecol 55, 322-329.

Jukes, T. H. \& Cantor, C. R. (1969). Evolution of protein molecules. In Mammalian Protein Metabolism, vol. 3, pp. 21-132. Edited by H. N. Munro. New York: Academic Press.

Kim, K.-H., Ten, L. N., Liu, Q.-M., Im, W. T. \& Lee, S.-T. (2006). Sphingobacterium daejeonense sp. nov., isolated from a compost sample. Int J Syst Evol Microbiol 56, 2031-2036.

Kumar, S., Tamura, K. \& Nei, M. (2004). MEGA3: integrated software for molecular evolutionary genetics analysis and sequence alignment. Brief Bioinform 5, 150-163.

Kuykendall, L. D., Roy, M. A., O'Neill, J. J. \& Devine, T. E. (1988). Fatty acids, antibiotic resistance, and deoxyribonucleic acid homology groups of Bradyrhizobium japonicum. Int J Syst Bacteriol 38, 358-361.

Mesbah, M., Premachandran, U. \& Whitman, W. B. (1989). Precise measurement of the $\mathrm{G}+\mathrm{C}$ content of deoxyribonucleic acid by highperformance liquid chromatography. Int J Syst Bacteriol 39, 159-167.

Murray, R. G. E., Doetsch, R. N. \& Robinow, F. (1994). Determinative and cytological light microscopy. In Methods for General and Molecular Bacteriology, pp. 21-41. Edited by P. Gerhardt, R. G. E. Murray, W. A. Wood, \& N. R. Krieg. Washington, DC: American Society for Microbiology.

Rainey, F. A., Ward-Rainey, N., Kroppenstedt, R. M. \& Stackebrandt, E. (1996). The genus Nocardiopsis represents a phylogenetically coherent taxon and a distinct actinomycete lineage: proposal of Nocardiopsaceae fam. nov. Int J Syst Bacteriol 46, 1088-1092.

Smibert, R. M. \& Krieg, N. R. (1994). Phenotypic characterization. In Methods for General and Molecular Bacteriology, pp. 607-654. Edited by P. Gerhardt, R. G. E. Murray, W. A. Wood \& N. R. Krieg. Washington, DC: American Society for Microbiology.

Steyn, P. L., Segers, P., Vancanneyt, M., Sandra, P., Kersters, K. \& Joubert, J. J. (1998). Classification of heparinolytic bacteria into a new genus, Pedobacter, comprising four species: Pedobacter heparinus comb. nov., Pedobacter piscium comb. nov., Pedobacter africanus sp. nov. and Pedobacter saltans sp. nov. Proposal of the family Sphingobacteriaceae fam. nov. Int J Syst Bacteriol 48, 165-177.

Tiago, I., Teixeira, I., Silva, S., Chung, P., Veríssimo, A. \& Manaia, C. M. (2004). Metabolic and genetic diversity of mesophilic and thermophilic bacteria isolated from composted municipal sludge on poly-\&-caprolactones. Curr Microbiol 49, 407-414.

Tindall, B. J. (1989). Fully saturated menaquinones in the archaebacterium Pyrobaculum islandicum. FEMS Microbiol Lett 60, 251-254. 